\title{
Perusteluja pässien fenotyyppitestaukselle
}

\author{
Mikko Varo ja Tapani Hellman \\ Helsingin Yliopis|o, kotieläinten jalostustieteen laitos
}

\section{Some arguments on the phenotype testing of rams}

Mikko Varo and TAPani Hellman

University of Helsinki, Department of Animal Breeding

\begin{abstract}
On the basis of the results of the growing experiments made with young rams in $1965-66$ the possibilities to estimate the quantity of meat and meatiness have been studied according to caracteristics which have been or can be measured also in living animals. For this reason in parallell with the measures of the living animals also some measures of carcass, fulfilling the above condition, have been used: the crossectional area of the m.l.d. can be obtained by an ultrasonic measurement, the circumference of the part of chump can be given as the circumference of the thigh, and the head weight can be substituted by the measured size of the head.

It can be expected according to the results of the stepwise multiple regression analysis that the amount of meat produced can be estimated in phenotype testing primarily using live weight, the crossectional area of the m.l.d. and the circumference of the thigh. The same qualities give also a satisfactory estimate of the meatiness.

In the progeny testing, used in control of phenotype testing, the carcass weight alone is a sufficient measure for the estimation of meat yield. In case it is desirable to emphasice meatiness in the progeny testing, this can be completed with the points of the carcass, circumference of the part of chump and the crossectional area of m.l.d.
\end{abstract}

\section{Johdanto}

Lampaanjalostusyhdistyksen koetilalla Hiirolassa v. 1965-66 järjestetyissä nuorten pässien kasvukokeissa, joiden tulokset on pääosaltaan julkaistu (VARO 1968), mitattiin myös pitkän selkälihaksen poikkileikkauspinta-alat. Koska nämä mittaukset tehtiin vain ensimmäisenä koevuonna, ne jäivät käsittelemättä kaksi laidunkautta jatkuneiden kokeiden kokonaistuloksia tarkasteltaessa. Ultraäänitekniikan kehittyminen niin, että selkälihaksen poikkileikkauspinta-ala on mitattavissa myös elävistä eläimistä, on antanut aikaisempaa suuremmat mahdollisuudet $\mathrm{li} \mathrm{ha} \mathrm{k} \mathrm{k} \mathrm{u} \mathrm{u} \mathrm{d} \mathrm{e} \mathrm{n}$ eli ruhon lihaprosentin arvioimiselle. Tästä syystä on tullut aiheelliseksi tarkastella voiko selkälihakseen perustuva lihakkuuden arvio hyödyllisesti täydentää pässien fenotyyp- 
pitestausta, jonka päätehtävä kuitenkin on kasvutaipumuksen mittaaminen. Edellä mainitussa tutkimuksessa lihakkuuden vaihtelun äärirajat olivat keskiarvon ja hajonnan mukaan $73.4-84.8 \%$. Näin suuren muuntelun hyväksikäyttö saattaa olla hyödyksi sekä lihamäärän että tuotteiden kauppa-arvon lisäämiseen pyrkivässä jalostusvalinnassa.

Nyt käsiteltävään aiheeseen liittyvät tärkeimmät koetulokset osoittivat, että nopea kasvu, jonka mittana on määräiässä saavutettu paino, on lampaanlihantuotannon perustekijä. Lihamäärän ja elo- sekä teuraspainojen fenotyyppikorrelaatiot olivat nimittäin $0.80^{* * *}$ ja $0.97 * * *$. Elopainon ja eräiden mittojen summavariaabeli antoi korrelaation $0.86^{* * *}$. Myös lihakkuus seuraa jossakin määrin painoja, mutta heikommin kuin lihan kilomäärä. Elopainon ja lihakkuuden korrelaatio oli $0.36^{* *}$ ja vastaavasti teuraspainon ja lihakkuuden 0.57***. Tutkimuksessa punnittiin erikseen vain lanneosasta erotettu pitkän selkälihaksen osa. Tämän pitkän selkälihaksen osan painon ja lihakkuuden välillä oli korrelaatio $0.51 * * *$. FIELD ym. (1963) ovat saaneet pitkän selkälihaksen painon ja lihakkuuden välille korrelaation 0.61. Nämä tulokset viittaavat siihen, että selkälihas saattaa antaa käyttökelpoisen perustan myös elävän eläimen lihakkuuden arvioimiselle.

Pitkän selkälihaksen poikkileikkauspinta-alan ja lihakkuuden välisen yhteyden on todennut myös LABEcka (1971). Rousen ym. (1970) saama vastaava korrelaatio oli sen sijaan negatiivinen, mikä tutkijoiden mukaan selittynee sillä, että painon suuretessa lihakkuus pienenee, ja toisaalta selkälihaksen poikkileikkauspinta-alan ja elopainon välillä vallitsee positiivinen korrelaatio 0.58. Koska poikkileikkauspinta-alan ja ruhon koko lihamäärän välillä on voimakas korrelaatio 0.65 , he pitävät selkälihasta parempana lihamäärän kuin lihakkuuden arviona. GöHLER ja LIEBEnberg (1972) saivat selkälihaksen poikkileikkauspinta-alan ja lihakkuuden välille korrelaatiokertoimen 0.52 ja GöHler (1973) 0.60. CUnNingham ym. (1967) toteavat, että pitkän selkälihaksen ala suhteessa ruhon painoon on ruhon laadun osoittajana muita heidän käyttämiään mittoja parempi. Lisäksi he ovat todenneet elävän eläimen reiden ympäryksen olevan voimakkaassa korrelaatiossa lampaanruhon kauppaarvoon.

Kirjallisuudesta ei ole vielä löytynyt tietoja ultraäänimittausten arvosta elävän eläimen lihakkuuden ennustajana. Sen sijaan Moody ym. (1965) ovat verranneet ultraäänellä elävästä eläimestä mitattua ja teurastuksessa todettua pitkän selkälihaksen poikkileikkauspinta-alaa keskenään. Kolmena vuonna todetut korrelaatiot vaihtelivat rajoissa $0.52-0.66$.

\section{Tutkimuksen suorittaminen}

Valikoivalla regressioanalyysillä on koetettu löytää käytettävissä olevien mittaustulosten joukosta ominaisuusyhdistelmät, jotka parhaiten arvioisivat ruhon todellista lihakkuutta. Selittäviksi ominaisuuksiksi otettiin elävien eläinten mittaustulokset. Niihin on kuitenkin liitetty mukaan kolme ruhosta saatua mittaa, selkälihaksen poikkileikkauspinta-ala, pään paino ja paistin ympärysmitta, jotka voidaan korvata elävästä eläimestä otettavilla mitoilla. Kaksi viimeksi mainittua mittaa on otettu mukaan, koska ne ovat korreloituneet voimakkaasti ruhon lihakkuuteen. Pään paino on korvattavissa sen kokoa 
arvioivilla mitoilla ja paistin ympärysmitta reiden ympärysmitalla tai ns. reisimitalla. Kaikkien mukana olevien mittojen keskiarvot ja hajonnat on esitetty taulukossa 1. Selkälihas I ja II ovat lanneosan etupään ja selkälihas III ja IV sen takapään katkaisukohdan vastakkaisista poikkileikkauspinnoista mitattuja pinta-aloja.

Aineistossa, johon myös tämä tutkimus perustuu, oli lihamäärän ja lihakkuuden korrelaatio $0.62^{* * *}$. Lihakkuuden lisääminen ei näin ollen ole ristiriidassa lihamäärän lisäämisen kanssa. Sen sijaan on mahdollista, että mitat, joilla näitä ominaisuuksia arvioidaan, voivat johtaa ristiriitaiseen arvosteluun. Tästä syystä lihakkuutta parhaiten arvioivien ominaisuuksien selitysasteet on laskettu myös lihamäärälle. Vastaavalla tavalla on laskettu myös lihamäärää parhaiten arvioivien ominaisuuksien molemmat selitysasteet.

Koska fenotyppitestausta tarkistavaan jälkeläisarvosteluun voidaan liittää teurasarvostelu, on lihakkuudelle ja lihamäärälle laskettu myös teurasominaisuuksien selitysasteet. Tällöin on tutkittu vain sellaisia mittoja, jotka voidaan saada ruohon arvoa leikkelyllä huonontamatta. Samassa tarkoituksessa on tutkittu myös teuraspainon, pään ja sisäelinten merkitystä lihakkuuden ja lihamäärän osoittajina. Saadut selitysasteet on esitetty taulukoissa 2 ja 3 .

Selitysaste mittaa standardiarvoin sen suhteellisen vaikutuksen, mikä selittäjäryhmällä on selitettävään. Selittäjiksi tulevat ominaisuudet, joiden yhteys selitettävään on suhteellisesti suurin, mutta joiden keskinäinen yhteys on heikko. Miinusmerkki (-) osoittaa, että ominaisuus on liittynyt selittäjiin negatiivisena, ts. sen mittaluvun pieni arvo on korostanut selitettävää ominaisuutta. Regressiokertoimen merkitsevyys, jolla uusi ominaisuus suurentaa selitysastetta, on osoitettu asteriskein tavalliseen tapaan: $\mathrm{P}<0.05^{*}, \mathrm{P}<0.01^{* *}$ ja $\mathrm{P}<0.001^{* * *}$.

\section{Tulokset}

\section{Lihakkuuden arvioiminen}

Lihakkuutta parhaiten arvioivien ominaisuusyhdistelmien selitysasteet ovat taulukossa 2. Kun selitysasteet on laskettu sekä lihakkuudelle että lihamäärälle, voidaan niitä keskenään vertaamalla nähdä, missä määrin samat ominaisuudet arvioivat lihatuotoksen molempia mittoja. Selitysasteiden numeroarvot sellaisenaan osoittavat, että lihakkuutta parhaiten arvioivat ominaisuudet arvioivat lihamäärää jopa paremmin kuin lihakkuutta. Mutta kun lisäksi otetaan huomioon myös merkki, havaitaan, että kaikki ominaisuudet eivät voi samanaikaisesti olla lihakkuuden ja lihamäärän selittäjinä. Niinpä elomittojen ryhmässä pään painon ja säkäkorkeuden mittalukujen pienet arvot viittaavat suureen lihakkuuteen, mutta suuret runsaaseen lihamäärään. Teurasmitoissa suuri selkälihas I-II on lihakkuuden, mutta pieni lihamäärän tunnus.

Havaituilla ristiriitaisuuksilla on useissa tapauksissa luonnollinen selitys. Aikaisemmin tehty faktorianalyysi osoitti, että pään ja luuston absoluuttipainot korreloituivat positiivisesti ruhon painoon ja kokoon sekä lihamäärään, kun taas pään suhteellinen paino korreloitui negatiivisesti ruhon lihak-

kuuteen. Nuorilla, vähän rasvoittuneilla eläimillä lihakkuuden määrää lihan ja luun suhde. Näiden yhteyksien vuoksi on helppo ymmärtää, miksi suhteellinen 
Taulukko 1. Tutkimuksessa tarkasteltavat ominaisuudet

Table 1. The averages and standard deviations of the traits in the study.

\begin{tabular}{lcc}
\hline Ominaisuus & Keskiarvo & Hajonta \\
Trait & Average & $S . D$. \\
\hline
\end{tabular}

Selitettävät ominaisuudet:

Lihamäärä $1 / 2$ ruhossa

Lihakkuus

Selittävät ominaisuudet:

Elopaino

Pisteet: rinta

lanne

reisi

yhteensä

Pituus

Rinnan syvyys

Säkäkorkeus

Rintakehän leveys

Lapojen leveys

Lantion etuleveys

Paistin ympärys

Pään paino

Teuraspaino

Ruhopisteet:

$$
\begin{aligned}
& \text { paisti } \\
& \text { satula } \\
& \text { säkä } \\
& \text { yhteensä }
\end{aligned}
$$

Luokittelupisteet

Selkälihas I-II

Selkälihas III-IV

Selkälihas I-IV

Selkälihaksen paino

Kylkipituus

Etupotka

Keuhkot

Maksa

Sydãn

Munuaiset

Munuaisrasva

Kieli

$-\mathrm{kg}-\begin{gathered}\text { Amount of meat in half } \\ \text { carcass }\end{gathered}$
$-\% \quad$ Fullness of meat

- \% - Fullness of meat

Independent traits:

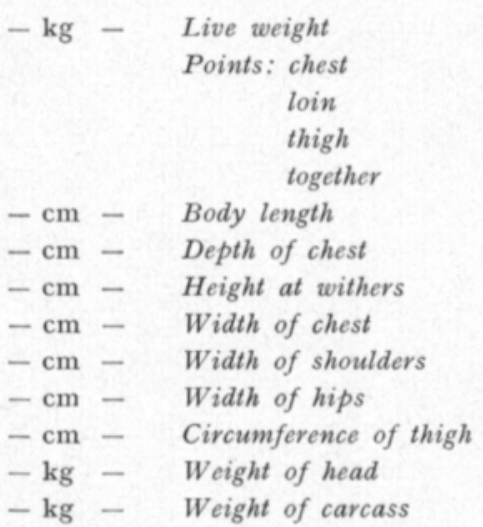

Points of carcass.

thigh
saddle
withers
together

Points of classification

$-\mathrm{cm}^{2}-$

$-\mathrm{cm}^{2}-$

M.l.d. I-II

$-\mathrm{cm}^{2}-$

M.l.d. III-IV

$-\mathrm{kg}-$

M.l.d. $I-I V$

$-\mathrm{cm}-$

Weight of M.l.d.

Length of side

Shin

- kg - Lungs

- kg - Liver

- kg - Heart

$-\mathrm{kg}-$

$-\mathrm{kg}-$

$-\mathrm{kg}-$
5.27

80.12

35.32

3.08

3.09

2.79

8.97

62.50

27.25

58.65

15.53

16.20

13.90

35.05

1.32

13.16

5.42

5.14

5.16

15.82

18.59

5.83

8.93

7.38

0.18

52.79

0.20

0.31

0.45

0.12

0.09

0.18

0.07
4.30

0.91

1.10

1.11

2.71

3.64

1.36

2.68

1.21

0.98

0.80

6.35

0.15

1.76

Selkälihas I-II on lanneosan etupäästä ja selkälihas III-IV sen takapäästä mitattujen pinta-alojen keskiarvo. Selkälihas I-IV on kaikkien pinta-alojen keskiarvo.

M.l.d. I-II is the mean of the two surfaces on the front cutting point of loin part and M.l.d. $I I I-I V$ is the corresponding mean of the rear cutting point. M.l.d. I-IV is the mean of the four surfaces on the two cutting points. 
Taulukko 2. Lihakkuutta arvioivat ominaisuudet

Table 2. The traits estimating the fullness of meat.

\begin{tabular}{cc}
\hline & Kumulativiset selitysasteet \\
Ominaisuudet & Cumulative coefficients of \\
Traits & determination $\left(\mathrm{R}^{2} \%\right)$ \\
& lihakkuudelle ja lihamääräle \\
& for fullness and amount of meat \\
\hline
\end{tabular}

Elävän eläimen mitat

Measurements of live animal

\begin{tabular}{|c|c|c|c|}
\hline Selkälihas I-II - M.l.d. $I-I I \quad \ldots \ldots \ldots \ldots \ldots . . . .$. & 23.0 & *** & 28.1 \\
\hline 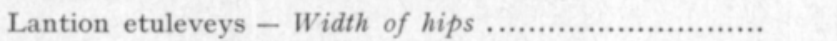 & 35.8 & $* *$ & 58.8 \\
\hline Rintakehän leveys - Width of chest .............. & 40.3 & * & 62.2 \\
\hline Pään paino - Weight of head ............................ (-) & 44.1 & * & 71.8 \\
\hline Paistin ympärys - Circumference of thigh & 47.7 & * & 78.9 \\
\hline Säkäkorkeus - Height at withers ............................ (-) & 49.5 & & 79.3 \\
\hline
\end{tabular}

Teurasmitat

Measurements of carcass

\begin{tabular}{|c|c|c|c|c|c|}
\hline sen paino - Weight of M.l.d. & 33.2 & * & & 56.1 & \\
\hline Luokittelupisteet - Points of classification & 46.3 & $* * *$ & & 56.9 & * \\
\hline Teuraspaino - Weight of carcass ............... & 50.3 & $* * *$ & & 95.5 & $* * *$ \\
\hline Pään paino - Weight of head & 55.8 & $* *$ & $(-)$ & 95.6 & \\
\hline Selkälihas I-II - M.l.d. I-II ... & 57.6 & ** & $(-)$ & 95.7 & \\
\hline Selkälihas III - IV - M.l.d. III-IV & 62.1 & $* *$ & $(-)$ & 95.9 & \\
\hline
\end{tabular}

Teuraspaino ja elimet

Weight of carcass and inner organs

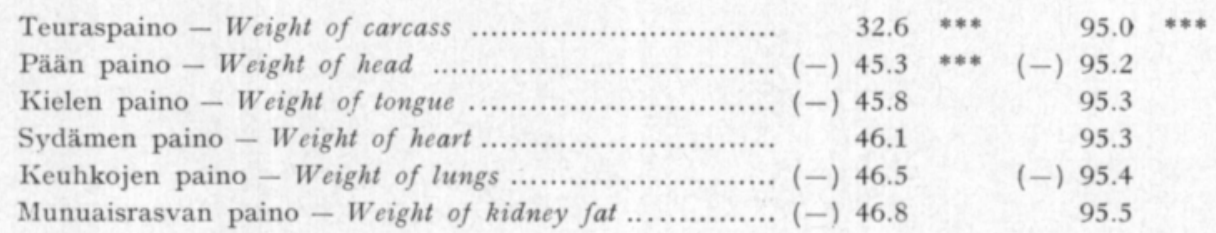

Kaikki ominaisuudet

All the traits

\begin{tabular}{|c|c|c|c|c|}
\hline Selkälihaksen paino - Weight of M.l.d. .................... & 33.2 & ** & 56.1 & ** \\
\hline Luokittelupisteet - Points of classification ................... & 46.3 & *** & 56.9 & $* *$ \\
\hline Pituus - Body length .................... & 50.9 & * & 65.5 & ** \\
\hline 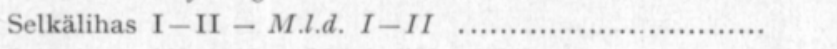 & 52.9 & * & 67.3 & \\
\hline Selkälihas III-IV - M.l.d. III-IV ................... (-) & 56.6 & & 67.5 & \\
\hline Pään paino - Weight of head .................................... (-) & 58.3 & & 76.4 & \\
\hline
\end{tabular}

pienipäisyys on aina tullut lihakkuuden selittäjäksi. Samoin saa selityksensä se, että pienipäisyys teuraspainon mukana ollessa on myös suuren lihamäärän tunnus. Koska suhteellinen pienipäisyys liittyy pieneen luustoon, täytyy sen samoissa ruhoissa liittyä paitsi lihakkuuteen samalla myös suureen lihamäärään.

Säkäkorkeuden sekä kielen ja munuaisrasvan painojen ristiriitaista yhteyttä lihakkuuteen ja lihamäärään on aiheetonta tarkastella lähemmin, koska niiden 
vaikutus on tilastollisesti merkitsemättömänä tulkittava lähinnä sattumanvaraiseksi. Sen sijaan on mielenkiintoista, että selkälihas I-II ja pitkän selkälihaksen paino ovat aina olleet positiivisessa, mutta selkälihas III-IV negatiivisessa yhteydessä lihakkuuteen. Kuten myöhemmin esitetään, on selkälihas III-IV ilmeisen epävarma mitta selkälihas I-II:een verrattuna, joten tässäkin voidaan siitä saadut yleensä tilastollisesti merkitsemättömät tulokset jättää vähälle huomiolle.

Tämän tarkastelun jälkeen voidaan yhteenvetona lihakkuuden arvioimisesta todeta, että elomittojen yhdistelmä: selkälihas I-II, lantion leveys ja rintakehän leveys, johtaa fenotyyppitestauksessa valintaan, joka varsin tyydyttävästi suosii lihakkaita ja samalla runsaasti lihaa tuottavia yksilöitä.

Jälkeläisarvostelun teurasarvostelussa ominaisuusyhdistelmä: pitkän selkälihaksen paino, teuraspisteet, teuraspaino, pään paino ja selkälihas I-II, antaa sangen hyvän arvion lihakkuudesta ja lähes täydellisen lihamäärästä. Varsin tyydyttävä lihakkuuden arvio saadaan myös teuraspainon ja pään painon yhdistelmällä, joka samalla arvioi lihamäärää lähes täydellisesti. Elinten painot eivät varmista arvostelua.

Kaikista ominaisuuksista kootulla yhdistelmällä ei ole muuta merkitystä kuin, että se kaikkien ominaisuuksien kilpaillessa keskenään vahvistaa selkälihaksen merkitystä lihakkuuden arvioijana. Samoin se osoittaa ruhojen pistearvostelun käyttökelpoisuuden. Edelleen voidaan tuloksesta päätellä, että onnistuneesti valitut elomitat voivat olla varsin tyydyttäviä lihakkuuden arvioita.

\section{Lihamäärän arvioiminen}

Taulukossa 3 esitetyt lihamäärän selitysasteet osoittavat selvemmin kuin taulukon 2 tulokset, että lihamäärä on paljon helpommin arvioitavissa kuin lihakkuus. Kaikissa arvosteluissa, joissa teuraspaino on mukana, se yksin riittää lihamäärän arvioimiseen. Muiden mittojen antama lisähyöty on niin pieni, että se tuskin korvaa niiden vaatimaa työmäärää. Näin ollen teurasarvostelun täydentäminen muilla tiedoilla on aiheellista vain, jos niillä on merkitystä lihakkuuden lisäämiselle.

Lihamäärän ennustaminen elävän eläimen mitoista on epävarmempaa kuin teuraspainosta. Kuitenkin elopaino yksinään antaa lihamäärästä jo melko hyvän arvion. Tieto selkälihaksen poikkileikkauspinta-alan koosta lisää arvion varmuutta erittäin merkitsevästi. Vielä paistin (= reiden) ympärysmittakin lisää selitysastetta merkitsevästi, mutta muiden mittojen vaikutus siihen jää jo suhteellisen pieneksi. Kaikki lihamäärää parhaiten arvioivat elomitat suosivat samalla lihakkuutta, joskin selitysasteet jäävät tämän tutkimuksen pienimmiksi. Ne ovat suuruudeltaan noin $1 / 2-3 / 4$ lihakkuutta parhaiten arvioivien ominaisuuksien antamista selitysasteista.

\section{Selkälihaksen pinta-alojen muuntelu}

Valikoiva regressioanalyysi osoitti selkälihaksen merkityksen sekä lihakkuuden että lihamäärän arvioimisessa. Selkälihaksen mittaus oli kuitenkin juuri teurastetuista karitsanruhoista verraten vaikeaa. Pehmeän lihaksen muoto 
Taulukko 3. Lihamäärää arvioivat ominaisuudet.

Table 3. The traits estimating the amount of meat,

\begin{tabular}{cc}
\hline & Kumulatiiviset selitysasteet \\
Ominaisuudet & Cumulative coefficients of \\
Traits & determination $\left(\mathrm{R}^{2} \%\right)$ \\
& lihamäärlle ja lihakkuudelle \\
& for amount and fullness of meat \\
\hline
\end{tabular}

Elävän eläimen mitat

Measurements of live animal

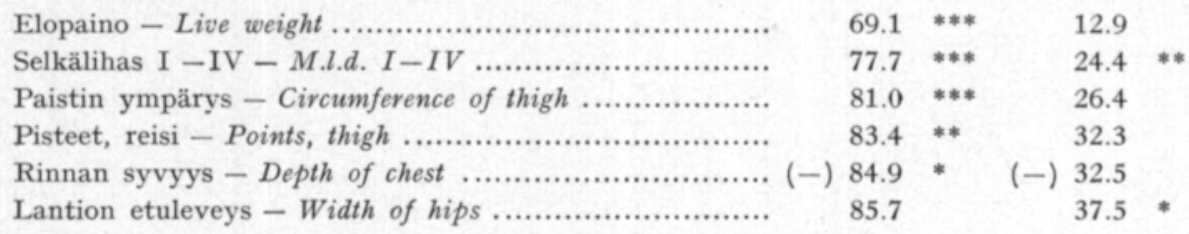

Teurasmitat

Measurements of carcass

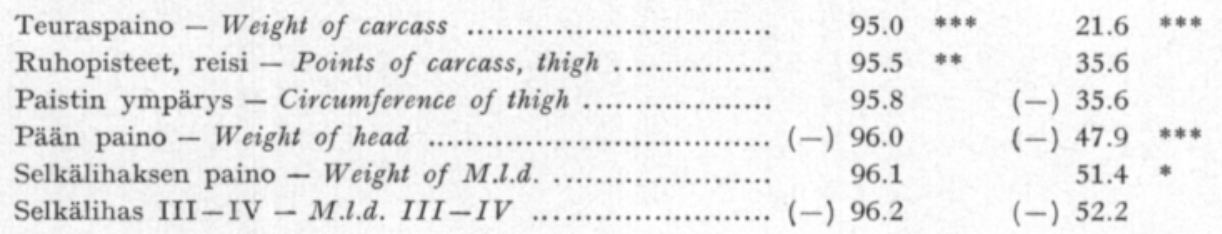

Teuraspaino ja elimet

Weight of carcass and inner organs

\begin{tabular}{|c|c|c|c|c|}
\hline Teuraspaino - Weight of carcass & 95.0 & $* * *$ & & \\
\hline Pään paino - Weight of head ............... & 95.2 & & $(-)$ & \\
\hline Maksan paino - Weight of liver ... & 95.3 & & & \\
\hline Keuhkojen paino - Weight of lungs ....................... (-) & 95.4 & & $(-)$ & \\
\hline Kielen paino - Weight of tongue ........ & 95.6 & & $(-)$ & \\
\hline Iunuaisten paino - Weight of kidneys ..................... (- & 95.6 & & $(-)$ & \\
\hline
\end{tabular}

Kaikki ominaisuudet

All the traits

\begin{tabular}{|c|c|c|c|c|}
\hline Teuraspaino - Weight of carcass & 95.0 & *** & & 32.6 \\
\hline Ruohopisteet, paisti - Points of carcass, thigh & 95.5 & $* * *$ & & 35.6 \\
\hline Paistin ympärys - Circumference of thigh ........ & 95.8 & * & & 35.6 \\
\hline Säkäkorkeus - Height at withers ............. & 96.0 & * & $(-)$ & 37.9 \\
\hline Pisteet, lanne - Points, loin .... & 96.3 & ** & $(-)$ & 38.2 \\
\hline Pisteet yhteensä - Points together & 96.6 & * & & 44.1 \\
\hline
\end{tabular}

muuttui ruhoa käsiteltäessä ja poikkileikkauspinta-alaa mitattaessa. Saman leikkauskohdan vastakkaisistakin pinnoista saadut piirrokset ja niiden pintaalat vaihtelivat. Etummaisten pinta-alojen I ja II korrelaatiokerroin oli $0.81 * * *$ ja takimmaisten III ja IV $0.80^{* * *}$. Saman poikkileikkaukohdan mittaukset eivät siis ole antaneet täysin yhtäpitävää tulosta. Tämä voidaan tulkita myös niin, että ultraäänikuvaukseen perustuva mittaus saattaa antaa lähes yhtä hyvän arvion lihakkuudesta. 
Selkälihaksen poikkileikkauspinta-alojen yhteys lihakkuuteen ja lihamäärään nähdään seuraavista korrelaatiokertoimista:

$\begin{array}{ccc}\text { Pinta-alat } & \text { Lihakkuus } & \text { Lihamäärä } \\ \text { I-II } & 0.48 & 0.53 \\ \text { III-IV } & 0.36 & 0.53 \\ \text { I-IV } & 0.45 & 0.59 \\ \text { I-IV Isittäin } & 0.61 & 0.77\end{array}$

Taulukosta 4 nähdään, että eri mittauskohtien pinta-alat eroavat erittäin merkitsevästi toisistaan. Myös yksilöt olivat keskenään errittäin merkitsevästi erilaisia. Erot kuvastavat samalla yksilöllisiä eroja lihaksen muodossa. Tähän viittaa yhdysvaikutus, joka osoittaa, että yksilöillä eri mittauskohtien pinta-alojen suhde on merkittsevästi erilainen. Tästä johtuva lisämuuntelu vaikeuttaa yksilöiden erottelua. Se puoltaisi eri mittausten keskittämistä rinta- ja lanneosan raja-alueelle.

Isien poikaryhmistä lasketut selkälihaksen poikkileikkauspinta-alojen periytymisasteet nähdään seuraavasta lukuasetelmasta:

$\begin{array}{cc}\text { Pinta-alat } & \mathrm{h}^{2} \\ \text { I ja II keskimäärin } & 0.43 \\ \text { I - II yhteensä } & 0.49 \\ \text { III ja IV keskimäärin } & 0.08 \\ \text { III-IV yhteensä } & 0.00 \\ \text { I-IV mitt. kohtien sisällä } & 0.35 \\ \text { I-IV yhteensä } & 0.16\end{array}$

Taulukko 4. Selkälihaksen poikkileikkauspinta-alojen yksilöllinen vaihtelu.

Table 4. The individual variation of the cross-sectional areas of the M.l.d.

\begin{tabular}{|c|c|c|c|c|c|c|c|c|c|}
\hline & $\begin{array}{c}\text { Muuntelun syy } \\
\text { Source of variation }\end{array}$ & $\begin{array}{l}\text { Neliösummat } \\
\text { Sum of squares }\end{array}$ & $\begin{array}{l}\text { V.a. } \\
d f\end{array}$ & $\begin{array}{l}\text { Keskineliöt } \\
\text { Mean square }\end{array}$ & $\mathrm{F}$ & $\left.{ }^{*}\right)$ & $\sigma^{2}$ & $\sigma^{2}-\%$ & \\
\hline 0 & $\begin{array}{l}\text { Kokonaismuuntelu ................. } \\
\text { Total }\end{array}$ & 112551.06 & 271 & 415.32 & & & 654.68 & 100 & \\
\hline 1 & $\begin{array}{l}\text { Mittauskohtien välinen } \\
\text { muuntelu ............................ } \\
\text { Between the points of } \\
\text { measurements }\end{array}$ & 65131,18 & 1 & 65131.18 & $7.71^{* * *}$ & (1.3) & 477.98 & 73 & 100 \\
\hline 2 & $\begin{array}{l}\text { Pintojen välinen muuntelu .. } \\
\text { Between the surfaces }\end{array}$ & 25.33 & 1 & 25.33 & - & & - & - & - \\
\hline 3 & $\begin{array}{l}\text { Yksilöiden välinen muuntelu } \\
\text { Between the individuals }\end{array}$ & 33383.31 & 67 & 498.26 & $3.95 * * *$ & (1.3) & 93.05 & 14 & 53 \\
\hline 1.3 & $\begin{array}{l}\text { Yhdysvaikutus ........................ } \\
\text { Interaction }\end{array}$ & 8447.07 & 67 & 126.08 & $3.05^{* * *}$ & (4) & 42.43 & 6 & 24 \\
\hline 4 & $\begin{array}{l}\text { Virhemuuntelu .................... } \\
\text { Error }\end{array}$ & 5564.17 & 135 & 41.22 & & & 41.22 & 6 & 23 \\
\hline
\end{tabular}

*) Numero viittaa sen muuntelulähteen keskineliöön, joka on ollut vertailuperusteena.

The number referes to the mean square of the source of variation the comparison has been based on. 
Nämä tulokset viittaavat siihen, että rinta- ja lanneosien raja-alueelta mitatut selkälihaksen poikkileikkauspinta-alat mittaavat parhaiten perinnöllisiä eroavuuksia. Kun ne myös mittaavat parhaiten lihakkuutta, näyttää ilmeiseltä, että selkälihaksen mittauskohdat fenotyyppitestauksen koevaiheessa on syytä tarkistaa niin, että ne antavat mahdollisimman hyvän kokonaiskuvan pässien jalostusarvosta.

Lihakkuuden ja Jihamäärän yhteisarvio

Taulukkoon $\mathbf{5}$ on kerätty edellä esitettyjen multippelikorrelaatioista (M) laskettujen selitysasteiden rinnalle myös summavariaabeleista (SV) eri tavalla lasketut selitysasteet sekä lihamäärälle että lihakkuudelle. Summavariaabelien

Taulukko 5. Elomittojen yhteisselitysaste lihamäärälle ja lihakkuudelle.

Table 5. The cumulative coefficient of determination for the amount and fullness of neat measured on live anima!s.

\begin{tabular}{lllllll}
\hline $\begin{array}{l}\text { Askel } \\
\text { Step }\end{array}$ & $\mathrm{M}_{\mathrm{L}}$ & $\mathrm{SV}_{\mathrm{L}}$ & $\mathrm{M}_{\mathrm{L} \%}$ & $\mathrm{SV}_{\mathrm{L} \%}$ & $\mathrm{SV}_{\mathrm{E}}+\mathrm{L} \%$ \\
\hline
\end{tabular}

Lihamäärän arvioiminen

Estimation of the amount of meat

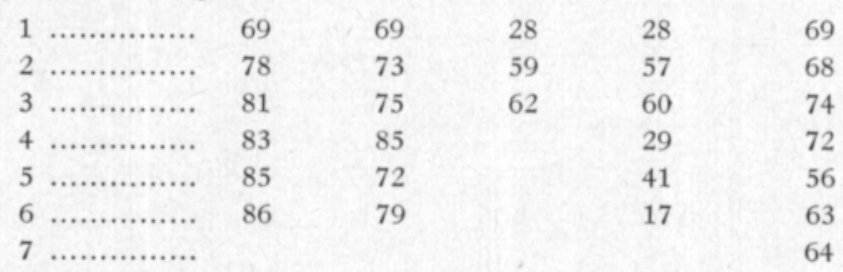

Lihakkuuden arvioiminen

Estimation of the fullness of meat

\begin{tabular}{|c|c|c|c|c|c|}
\hline 1 & 13 & 13 & 23 & 23 & 13 \\
\hline 2 & 24 & 24 & 36 & 36 & 26 \\
\hline 3 & 26 & 23 & 40 & 39 & 31 \\
\hline 4 & 32 & 30 & 44 & 41 & 34 \\
\hline 5 & 33 & 28 & 48 & 41 & 40 \\
\hline 6 & 38 & 32 & 50 & 38 & 38 \\
\hline 7 & & & & & 29 \\
\hline
\end{tabular}

\footnotetext{
M = multippelikorrelaatioon perustuva tulos. the result based on a multiple correlation

SV = summavariaabeleihin perustuva tulos the result based on sum variables

L = selittäjinä lihamäärää parhaiten arvioivat ominaisuudet the predictors are the traits best estimating the amount of meat

$\mathrm{L} \%=$ selittäjinä lihakkuutta parhaiten arvioivat ominaisuudet the predictors are the traits best estimating the fullness of meat

$\mathrm{E}+\mathrm{L} \%=$ selittäjinä elopaino + edelliset $(\mathrm{L} \%)$ the predictors are the live weight and the traits mentioned before ( $L \%)$
}

Selitysasteet ovat ilman nollia ja desimaalipisteitä.

The coefficients of determination are without zeros and desimal points. 
muodostaminen ja niiden yhteiskorrelaatioiden laskeminen on tapahtunut korrelaatiomatriiseista. Summavariaabeleiksi on yhdistetty lihamäärän (L) tai lihakkuuden (L \%) parhaiksi selittäjiksi osoittautuneet ominaisuudet tai viimeksimainittujen ja elopainon yhdistelmä $(E+L \%)$. Summavariaabeleissa ominaisuudet yhdistetään painottamattomin standardiarvoin. Siitä syystä niistä saadut selitysasteet ovat voineet jäädä pienemmiksi kuin multippelikorrelaatioista lasketut: Taulukosta voidaan kuitenkin nähdä, että varsinkin alkuaskelilla erot ovat yleensä sangen pienet.

Lihakkuutta parhaiten arvioivien ominaisuuksien lihamäärälle antamista selitysasteista on esitetty vain ne kolme ensimmäistä askelta, jotka saatiin samanmerkkisistä arvoista kuin lihakkuudenkin sєlitysasteet. Sammavariaabelista laskettu vastaava tulos osoittaa, että seuraavilla askelilla pienenee lihamäärän selitysaste ratkaisevasti pään painon ja säkäkorkeuden vastakkaisen vaikutuksen vuoksi lihamäärään ja lihakkuuteen. Näitä mittoja ei siis voi sisällyttää indeksiin, jossa painotuksen tulee ensisijaisesti olla lihamäärää lisäävillä ominaisuuksilla. Lihakkuutta ei voine sen paremmin tuotannollisista kuin taloudellisistakaan syistä pitää niin tärkeänä tavoitteena, että sen lisääminen voisi tapahtua lihamäärän kustannuksella.

Taulukon viimeiset sarakkeet esittävät tuloksia, jotka on saatu elopainosta ja lihakkuutta parhaiten arvioivista ominaisuuksista muodostetulla summavariaabelilla. Tämä yhdistelmä korostaa lihakkuutta jonkin verran enemmän kuin lihamäärää parhaiten arvioivat ominaisuudet yksinään, mutta samalla lihamäärän selitysaste pienenee. Pieneneminen on niin voimakas, että lihakkuuden lisääntymisestä johtuva ruhon kauppa-arvon mahdollinen paraneminen tuskin voi sitä korvata. Näyttää ilmeiseltä, että fenotyyppitestauksessa on pyrittävä käyttämään valinnan perusteina ominaisuuksia, jotka parhaiten arvioivat lihamäärää, mutta jotka samalla korostavat tyydyttävästi lihakkuutta. Tällöin lihakkuus tulee painotetuksi valinnassa sillä määrällä, joka vastaa lihakkuuden merkitystä lihamäärän osatekijänä. Tämä tavoite lienee myös turvallisin, koska se ei pyri voimakkaasti lihan ja luun suhteen muuttamiseen, jonka lopullista vaikutusta ei tunneta.

\section{Tulosten tarkastelu}

Suomalaisella lampaalla on ominaisuuksia, jotka tekevät sen hyväksi lihaeläimeksi: se on sikiävä ja hyväkasvuinen (KANGASNIEmr 1967). Myös jalostuksen kohteena se on lupaava, koska siinä on lihantuotannon kehittämiseksi runsaasti perinnöllistä muuntelua (VARO). Tämä tutkimus osoittaa, että sen suurta lihamäärän ja Jihakkuuden muuntelua voidaan jo fenotyypistä arvioiden käyttää valinnassa tuloksellisesti hyväksi. Valintaa on omiaan yksinkertaistamaan se, että eräät helposti saatavat mitat ovat varsin kiinteässä yhteydessä samanaikaisesti sekä lihamäärään että lihakkuuteen. Lampaalla, kuten muillakin eläimillä, keskeisten tuotanto-ominaisuuksien jalostaminen voidaan suurimmaksi osaksi hoitaa uroseläinten valinnalla. Fenotyyppitestaus on helppo toteuttaa laidunkautena, jolloin koeolosuhteet periaatteessa vastaavat niitä olosuhteita, joissa lampaanlihan tuotanto yleensäkin tapahtuu.

Tässä tutkimuksessa saadut selitysasteet voidaan tulkita niin, että selkälihaksen poikkileikkauspinta-aloista todetut lihakkuuserot ovat riittävän suuret 
vaikuttamaan myös lihamäärään. Selkälihasmitat ovat lisänneet jopa voimakkaammin lihamäärän kuin lihakkuuden selitysastetta, mikä on sopusoinnussa Rousen ym. havaintojen kanssa. Selkälihaksella on välitön vaikutus kyljys- ja satulaosan kauppa-arvoon. Tässä mielessä eräät tutkijat (BAILEY ym. 1961) ovat jopa tarkastelleet elo- ja teurasmittojen käyttökelpoisuutta selkälihaksen poikkileikkauspinta-alan arvioimisessa.

Mitä muita lihamäärää parhaimmin arvioivista ominaisuuksista otetaan mukaan fenotyyppitestaukseen riippuu siitä, kuinka paljon työtä voidaan arvosteluun uhrata. Lihamäärän arvioimisessa useista mitoista saatu lisähyöty jää vähäiseksi, mutta lihakkuuden lisäämiseksi kaikki tässä käytetyt mitat olisivat tarpeen. Alkuvaiheessa olisi suotavaa kokeilla vielä muitakin mittoja. CUNNINGHAM ym. havaitsivat, että elomitoista sekä reiden ympärysmitta että istuinkyhmyn ja kintereen väli olivat merkitsevässä yhteydessä ruhon kauppaarvoon.

Niin kuin edellä jo on mainittu, on fenotyyppitestaukseen syytä liittää myös jälkeläisarvostelu. Se on välttämätöntä viimeistään silloin, kun lampaan keinosiemennysjalostus saadaan käyntiin. Jälkeläisarvostelu tarkistaa ja täydentää fenotyyppitestauksen tuloksen ja antaa tietoa muistakin lihantuotantoon liittyvistä jalostettavista ominaisuuksista. Jotta jälkeläisarvostelun teurasarvosteluvaihe ei muodostuisi rasitukseksi, joka veisi mielenkiinnon koko pässien valinnalta, on se suunniteltava mahdollisimman yksinkertaiseksi. Tämän tutkimuksen tulos osoittaa, että vaatimusta on helppo noudattaa koska teuraspaino yksinäänkin riittää lihamäärän mitaksi. Helppotöinen täydennys saadaan ruhon pistearvostelusta, joka korostaa lihakkuutta.

Käytännössä fenotyyppitestaus ja jälkeläisarvostelu toteutetaan saman kokeen eri vaiheina. Tästä seuraa, että jälkeläisryhmien parhaat yksilöt valitaan jalostuseläimiksi. Että tämä valinta ei vääristäisi jälkeläisarvostelun teurasarvostelutulosta, olisi teurasarvosteluun otettava elopainoltaan jälkeläisryhmien keskipainoa parhaiten vastaavat yksilöt. Jälkeläisryhmät olisi näin ollen muodostettava kyllin suuriksi, että fenotyyppiin perustuvalle valinnalle jäisi riittävästi mahdollisuuksia.

Jälkeläisarvostelu tarjoaa mahdollisuuden myös kaikkien jalostettavien ominaisuuksien yhteistarkasteluun. Vaikka lihantuotanto onkin lampaankasvatuksen voimakkain kannustin, on myös villan ja turkin laatua syytä seurata. Bоткіn ym. (1971) ovat todenneet, että villatuotos ja villakuidun pituus ovat negatiivisessa korrelaatiossa lihantuotanto-ominaisuuksiin, $\mathrm{mm}$. kasvuun ja teuraslaatuun. ERмекоv ja SкоRoвogatov (1968) ovat puolestaan havainneet, että puolihienovillaisten lampaiden ruhon ja lihan arvo, selkälihaksen paksuus ja rehun hyväksikäyttö olivat paremmat kuin hienovillaisilla lampailla. Lampaan tuotantokyvyn kehittämisessä on tuotantokykyä siis tarkasteltava kokonaisuutena, mikä on riittävän luotettavasti mahdollista vain jälkeläisarvostelulla. Suomalaisen lampaan osalta lisäksi sikiävyys ja imetyskyky ovat jalostusarvostelussa varteenotettavia erikoispiirteitä. Äsken mainitut villan- ja lihantuotannon yhteyttä koskevat tutkimustulokset osoittavat joka tapauksessa, että jalostustavoitteiden perusteellinen tarkistus on tarpeen, jos lampaanlihantuotannon järjestelmälliseen kehittämiseen ryhdytään. 


\section{Päätelmät}

Tutkimuksen tulos osoittaa, että selkälihaksen poikkileikkauspinta-ala täydentää merkitsevästi totetun lihamäärän ja lihakkuuden elopainoon perustuvaa arviota nuorilla pässeillä. Koska selkälihaksen poikkileikkauspinta-alan täsmällinen mittaus nuorten karitsoiden ruhosta tuotti vaikeuksia, voidaan odottaa, että ultraäänikuvaukseen perustuva mittaus saattaa johtaa likimain yhtä tarkkaan arvioon. Kuvausmenetelmän kokeilu pässien fenotyyppitestauksessa on sen vuoksi perusteltua. Myös muilla elävistä eläimistä saatavilla mitoilla, kuten mm. reiden ympärysmitalla ja sen pistearvolla, saattaa olla merkitystä fenotyyppitestauksessa sekä lihamäärän että lihakkuuden arvioimisen varmistajana. Samat mitat, jotka arvioivat tuotettua lihamäärää, arvioivat tyydyttävästi ja riittävästi myös lihakkuutta. Fenotyyppitestaukseen liitettävässä jälkeläisarvostelussa teuraspaino antaa riittävän arvion tuotetusta lihamäärästä. Ruhon pistearvostelu (= luokitus) täydentää jälkeläisarvostelua korostamalla lihakkuutta.

\section{KIRJALLISUUS}

Bailey, C. M., Pope, A. L. \& Champman, A. B. 1961. Predicting loin-eye area in lambs from weanling traits and carcass measurements. J. Anim. Sci. 20:302-306.

Botkin, M. P., Riley, M. L., Field, R. A., Johnson, C. Leroy \& Roehrkasse, G. P. 1971. Relationship between productive traits and carcass traits in lambs. J. Anim. Sci. 32: $1057-1061$.

Cunningham, N. L., Carpenter, Z. L., King, G. T., Butler, O. D. \& Shelton, J. M. 1967. Relationship of linear measurements and certain carcass characteristics to retail value, quality and tenderness of ewe, wether and ram lambs. J. Anim. Sci. 26: 683-687.

Ermekov, M. A. \& Sкоrobogatov, Ju. A. 1968. [Meat characters of muttonwool semifinewooled sheep.] Vest. sel'. -khoz. Nauki, Mosk. 13 (8): 71-74. Russ. with Eng., Ger., Fr. summs. Ref. Anim. Breed. Abstr. 37: 458.

Field, R. A., KemP, J. D. \& VARNey, W. Y. 1963. Indices for lamb carcass composition. J. Anim. Sci. 22: 218-221.

GöHLER, H. 1973. Massstäbe zur Bestimmung des Schlachtkörperwertes beim Schaf. Arch. Tierzucht 16, 3:243-250.

- - - \& LIEBenberg, O. 1972. Ein Beitrag zur Schlachtwertbestimmung beim Schaf. Arch. Tierzucht 15, 6: 429-439,

KANGASNIEMI, R. 1967. Karitsan syntymä- ja 150 päivän painon välisestä suhteesta sekä karitsapainoihin vaikuttavista tekijöistä suomalaisella maatiaislampaalla. Laudaturtyō.

LABECKA, S. 1971. [Carcass characters of Kent sheep kept under production conditions in the Szczecin district of Pomerania.] Zeszyty Naukowe, Wyzsa Szkola Rolnicza w Szczecinie (1971) No: 36, Zootechnika 6,61-83. Pl, De, Ru. Ref. Anim. Breed. Abstr. 41: 3084.

Moody, W. G., Zobrisky, S. E., Ross, C. V. \& NaUmann, H. D. 1965. Ultrasonic estimates of fat thickness and longissimus dorsi area in lambs. J. Anim. Sci. 24:364-367.

Rouse, G. H., Topel, D. G., Vetter, R. L., Rust, R. E. \& Wickersham, T. W. 1970. Carcass compositition of lambs at different stages of development. J. Anim. Sci. 31: 846-855.

VARo, M. 1968. Lampaiden kasvukokeiden tuloksia. Summary: Results of rearing trials with Finnish sheep. Ann. Agric. Fenn. 7:33-45.

Käsikirjoitus saapunut 12.11.1975 